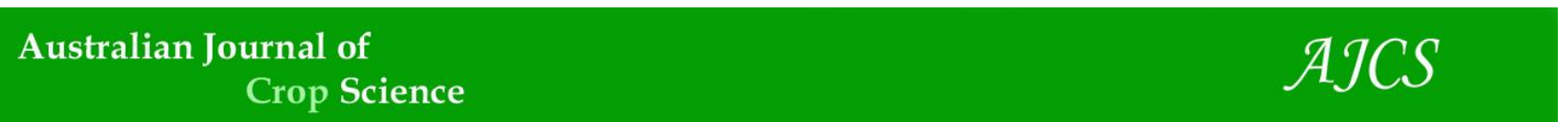

AJCS 15(04):518-523 (2021)

ISSN:1835-2707

doi: 10.21475/ajcs.21.15.04.p2789

\title{
Effect of the season on establishment of some turf grasses under the climatic conditions in eastern Morocco
}

\author{
Khadija CHARIF ${ }^{* 1}$, Ibtissam MZABRI ${ }^{1}$, Maria RIMANI², Azzouz BOUKROUTE ${ }^{1}$, Noureddine \\ KOUDDANE ${ }^{1}$, Abdelbasset BERRICHI ${ }^{1}$
}

\author{
${ }^{1}$ Laboratory, Agricultural Production Improvement, Biotechnology and Environment, Department of Biology, \\ Faculty of Sciences, University of Mohammed First, Oujda, Morocco \\ ${ }^{2}$ Laboratory Bioresources, Biotechnology, Ethnopharmacology and Health, Department of Biology, Faculty of \\ Sciences, University of Mohammed First, Oujda, Morocco
}

*Corresponding author: khadijachariff@gmail.com

\begin{abstract}
The turfgrass establishment is an important criterion for the choice of turfgrass species. The faster a lawn is established the more benefits it has to offer for landscapers. The objective of this work is to study the growth speed and development of six species. Four of them are cool-season ones (temperate): Lolium perenne, Festuca arundinacea, Agrostis stolonifera and Poa pratensis while the other two are warm-season ones (tropical): Pennisetum clandestinum and Cynodon dactylon. The species are seeded in two distinct periods: spring and autumn and are studied under the climatic conditions of the eastern region of Morocco which is characterized by a semi-arid Mediterranean climate with continental tendency known for its severe cold in winter. The coverage rate is the parameter considered in order to determine the duration of establishment for each species. The study was conducted in the experimental station of the Faculty of Sciences of Oujda. The results show that the establishment pace differs depending on the season and the nature of the species. Autumn is the suitable season for temperate species, while tropical species have shown a faster growth in spring. Lolium perenne and Cynodon dactylon are the fastest species to establish as they need a maximum of 30 days after the seedlings' development. Poa pratensis is the last species to cover the total area seeded within 50 and 60 days during the two season's spring and autumn respectively.
\end{abstract}

Keywords: establishment, spring and autumn, cool-season, warm season, Coverage rate.

Abbreviations: NTEP_National Turf Evaluation Program, DIA_Digital Image Analysis, DGCI_Dark Green Color Index, HSB_Hue, Saturation and Brightness, RGB,_Red Green Blue, INRA_National Institute of Agronomic Research, LAPIBE_Laboratory, Agricultural Production Improvement, Biotechnology and Environment, LNOLA_Laboratory of Nonlinear Analysis; FSO_Faculty of Sciences, Oujda.

\section{Introduction}

The lawn enhances the aesthetic, economic, and environmental value of green spaces and provides a recreational canvas, erosion control, and other ecological benefits (Beard, 1973; Busey, 2003 a). The mode of establishment of a lawn turf differs from one planner to another and so do the types of use as well as the period and of the objective of the establishment. Turf grasses can be established by vegetative means (rhizomes and stolon's) or by sexual reproduction (seedling). However, species such that the ryegrass (Lolium perenne) and tall fescue (Festuca arundinacea) are multiplied by seeds (Perez et al., 1995). Seedling is the most frequently used method of establishment in turfed areas (Christians, 1998). This method reduces the costs of establishment to the minimum (Burton, 1992) and is commonly practiced because of the ease of transport, storage and propagation of seeds (Christians, 1998; Watschke and Schmidt, 1992). The essential factors which influence the establishment have an important effect on any agricultural crop especially for the turf: when an establishment is incorrect or delayed, it may cause significant problems that could persist throughout the life of that crop (Richardson et al 2001). Cool-seasons species establish better when sown in September or October while the warm-seasons turf grasses establish better when seeded in April or May (Ries and Hofmann, 1996; Lang et al., 1975 in Richard et al., 1986). In order to maximize the growth and avoid the cold season (winter) or high temperatures stress (summer), it is recommended to sow the cool-season turf grasses in late summer, although the spring or the autumn seedings are often used out of necessity or convenience (Stier, 2000). Furthermore, the requisite time duration to achieve the turf's development from its seeding and before it can withstand stamping may vary depending on the turfgrass species or the used mixtures.Thus, perennial ryegrass establishes faster than the Kentucky bluegrass (Stier et al., 2008). This species establishes rapidly in fertile, moist soils and grows vigorously to compete with weeds (Hulke et al., 2008; Hoffman et al., 2010; 2012). Christians (1998); Dunn and Diesburg; (2004) indicate that the tall fescue is usually sown at the end of the summer or in the mid- autumn to avoid competition from summer weeds. The same authors found that the spring 
seeding of cool-seasons turf grass is challenging due to the stresses that occur during the summer such as heat, drought, and weeds. It has also been reported that the tall fescue "var Roa" has always been slow compared to ryegrass's fast establishment (Brock et al., 1982 in Hare, 2010). As a general rule, turf grasses of the warm season have a good behaviour in summer in contrast to the cool season ones that behave well during the coldest months (Jiang and Huang, 2000; Richardson et al., 2008).

In this study, different methods have been used to assess and monitor the establishment of the turf. The determination of the area covered by grass is a term that was introduced by Beard (1973) to numerically describe the degree of conformity of a turf to an agreed standard. This criterion is often based on a visual evaluation system developed by the National Turf Evaluation Program (NTEP) with a scale from 1 to 9 (with 1 representing the lowest quality and 9 the highest quality). A rating of 6 is considered minimally acceptable (Horst et al., 1984; Morris, 2002). This scale is based on the judgment of the evaluator and integrates mainly color, density and uniformity (Horst et al., 1984; Krans and Morris, 2007). Differences in human estimates result from the fact that individuals differ in their ability to perceive different wavelengths of visible light which may lead to differences in visual estimates of turf quality (Mirik et al., 2006). This scoring system is biased because of the subjectivities of evaluators and gives an inaccurate estimate of turf quality (Trenholm et al., (1999); Keskin et al., 2003; Krans and Morris (2007)). The alternative method to evaluate vegetated areas is the processing of digital images. This technique has been used to quantify the coverage of wheat (Lukina et al., 1999), soybeans (Purcell, 2000) and the turf grass (Richardson et al., 2001). Karcher and Richardson (2003) also found that Digital Image Analysis (DIA) strongly agrees with visual assessments of turf color. The same authors developed an index called the Dark Green Color Index (DGCl) using the levels of Hue, Saturation and Brightness (HSB). They noted an important agreement between DGCl and the visual assessment. It has also been shown that (DIA) accurately quantifies turf establishment (Shaver et al., 2006; Schiavon et al., 2012). The speed of lawn grass installation has been the subject of study for several researchers, particularly in countries with mild climate in Western countries. The tests in the aforementioned conditions are common, whereas ones focusing on climates such as the Moroccan one are almost non-existent. Thus, this work aims to study and compare the establishment pace of a few turf grasses that were installed in both spring and autumn in the prevailing climatic conditions in the Eastern region of Morocco.

\section{Results}

Analysis of the turf images using ImageJ software shows that the rate of turf establishment differs depending on the type of species and the season.

\section{Comparison of establishment speed between turf grass species}

Following the coverage rate of the species studied during the spring and autumn, it appears that all species follow an increasing rate of growth after seeding. The establishment speed describes a sigmoidal shape with three phases: a first phase known as the latency phase due to imbibition (the physiological germination), a second exponential phase where growth is accelerated, and a third and final stationary phase indicating the total coverage of the turf grassed area. Analysis of Figure (1) shows that there are three groups to be distinguished: The first one represents the following species: Cynodon dactylon, Lolium perenne and Pennisetum clandestinum. This group is characterized by a relatively short latent phase and an exponential phase which promotes a rapid coverage of the turf area. The second group consists of the two species Festuca arundinacea and Agrostis stolonifera with an average coverage rate compared to the other two groups. The third group has a single species Poa pratensis and is characterised by a long latent phase, a very spread out exponential phase, and a remarkable delay in total cover compared to the other species.

Monitoring of the establishment installation of six turf grass species during the autumn (Fig 2) identifies 3 groups. The one represented by the single species: Lolium perenne stands out from the others as the fastest one to settle. The second group, known as the medium speed group, includes the species Festuca arundinacea, Agrostis stolonifera, Cynodon dactylon and Pennisetum clandestinum. The third group as well as the spring period is both represented by the species Poa pratensis whose establishment is the most spread out in time. On the other hand, the analysis of the time required for total ground cover by the species studied during the two seasons (Fig 3) shows that, in general, a total coverage of seeded land requires an average of 42 to 45 days in autumn and spring respectively. So-called warmspecies require less time to cover the entire ground in spring than they do in autumn. In contrast, so-called cool-species cover the soil faster when sown in autumn compared to when they're sown spring (Fig 4). The species Lolium perenne and Cynodon dactylon are the fastest to cover the soil compared to other species requiring 30 and 41 days respectively in autumn and spring. Cash: Pennisetum clandestinum, Festuca arundinacea and Agrostis stolonifera require between 37 and 55 days for autumn coverage. Poa pratensis appears to be the slowest turf to cover the soil in all seeding seasons needing 50 and 60 days in the autumn and spring respectively (Fig 5). This is confirmed by the analysis of variance which revealed that the effect of the species on establishment speed is highly significant $(p<0.001)$. It was also reported that there is a significant difference $(p<0.05)$ between the spring and autumn seasons observed for Lolium perenne, Cynodon dactylon, Pennisetum clandestinum and Festuca arundinacea (Fig 5).

\section{Discussion}

The analysis of the digital images allowed us to determine the establishment rate of the species studied under the climatic conditions of the city of Oujda during the spring and autumn periods of 2017 . Results show that turf grass establishment differs depending on the species and the season. Among the species studied, Lolium perenne and Cynodon dactylon were the fastest to become established establish requiring 35 days only to cover the entire seeded soil. However, Poa pratensis was the last species to cover the entire seeded area, as it needed over 50 days to achieve full coverage. While autumn has been shown to be the right season for the rapid establishment of cool- season species, spring has been the right season for turf of warm-season origin. These results can be explained by various biological and eco-physiological factors, particularly climatic conditions such as temperature which plays an essential role in plant growth. In fact, the temperatures recorded during the 


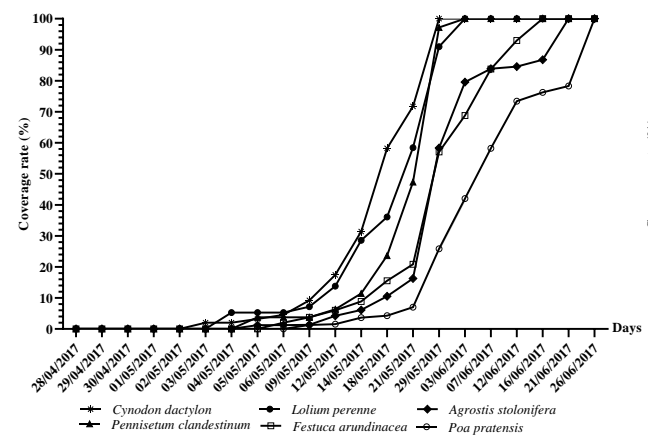

Fig 1. Coverage rate of the species studied during spring

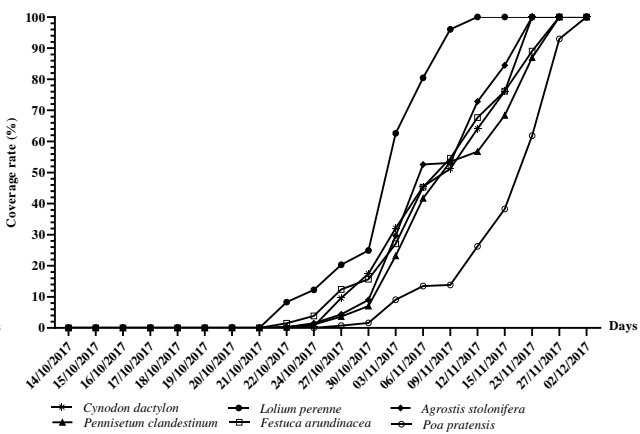

Fig 2. Coverage rate of species studied during autumn

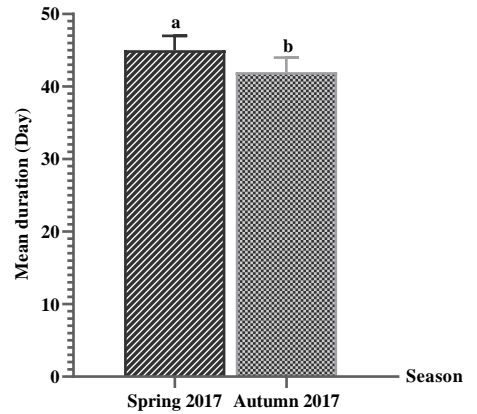

Fig 3. Duration of installation depending on seeding season

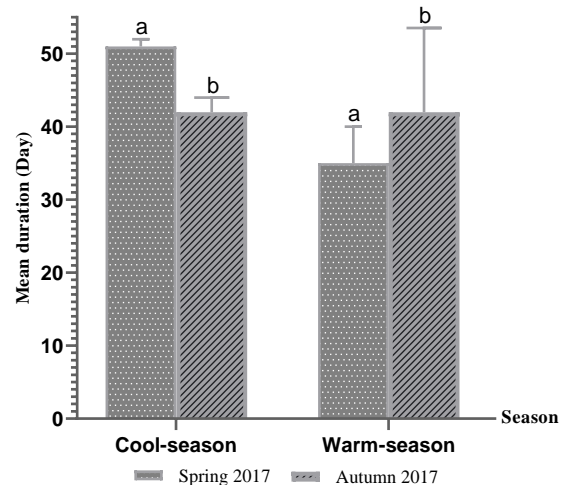

Fig 4. Duration of installation depending on the origin of turf species

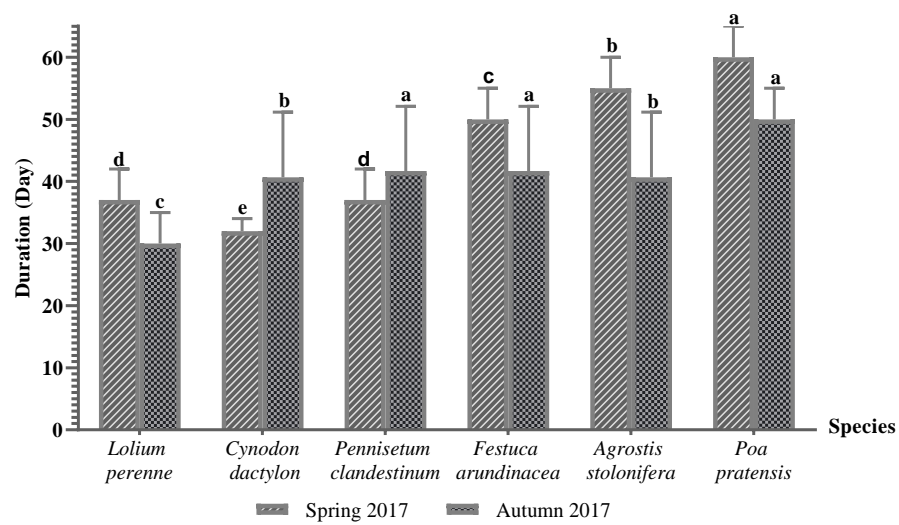

Fig 5. Duration necessary for a total coverage of the soil seeding by the six species studied during the spring and the autumn.

periods of our trials vary between 17 and $31^{\circ} \mathrm{C}$ during spring, while those marked during autumn range between 10 and $25^{\circ} \mathrm{C}$ which is considerable for the growth of these turf grasses. Smiley et al., 1992, reported that cool-season turf grasses are adapted to temperate regions with optimum growth occurring between 15 and $25^{\circ} \mathrm{C}$. Contrastingly, armseason species are adapted to tropical and subtropical regions, with optimal growth occurring between 25 and $35^{\circ} \mathrm{C}$. Moreover, other studies have reported that many factors influence the rate of growth and turf establishment speed such as meteorological conditions, species and

cultivar (Ruemmele et al., 1993; Watson, 1989; Roche and Loch, 2005), the amount of vegetative material used, and the management practices adopted during establishment (Gibeault et al. 1988; Guertal et al, 2006; Johnson, 1973, Munshaw et al. 2002; Patton et al. 2004; Portz et al. 1981; Rodriguez et al, 2000; Trenholm et al., 1997). Similar results were obtained by Stefano et al, (2012) who compared the establishment and performance of the three cool-season species hybrid bluegrass (Poa arachnifera Torr. $\mathrm{x}$ Poa pratensis $\mathrm{L}$ ), kentucky bluegrass (Poa pratensis) and tall fescue (Festuca arundinacea) under Mediterranean climate. They found that plots sown in autumn had a higher green cover $(80 \%)$ compared to plots sown in spring $(73 \%)$. Differences in ground cover between autumn and spring sodded plots may be justified by the cooler temperatures during the autumn establishment period. Christians (1998); Dunn and Diesburg (2004) found that tall fescue is generally seeded from late summer to autumn to avoid competition from warm season weeds. Establishing cool season turf afterspring seeding is extremely difficult due to a combination of stresses that occur during the summer months, including heat, water stress and weed interference. As a result, higher seeding rates are recommended for spring seeding due to the higher seed mortality in the 
summer (Christians, 1998). Our results are also consistent with those reported by Ward et al, (1973) who found that perennial ryegrass (Lolium perenne) provides rapid establishment whereas Poa pratensis is slow to establish. Similarly, Huff, (2003) reports that spring establishment in Mediterranean transition areas is generally difficult for coolseason species and particularly for Poa pratensis, because germination and subsequent establishment occur slower compared to other cool-season turf grasses. If seeding is not done at the right time, the summer heat can delay the growth and establishment of the turf. Reicher et al. (2000) also attributed the slow establishment of Poa pratensis from Virginia to high temperatures after the first few months of seedling. The authors also reported that the establishment of Festuca arundinacea was less affected by sowing date than Poa pratensis.

Our results also show that Bermudagrass (Cynodon dactylon) establish quickly during the spring. The same findings were observed by Munshaw et al., (1998); Hensler et al., (1999) for the same species in late spring. It has also been reported that seeding dates in April and May improved winter survival of Bermudagrass compared to late seeding dates in June and July in Arkansas (Richardson et al., 2004). These results confirm that the season has an impact on the establishment of turfgrass species as reported in our study.

\section{Materials and Methods}

\section{Plant material}

This test has focused on six turf grasses widely represented in the lawns of Morocco. These are cool-seasons species: Lolium perenne, Festuca arundinacea, Agrostis stolonifera, Poa pratensis, and warm-seasons species: Pennisetum clandestinum and Cynodon dactylon (Table 1).

The seeds were donated by the seed producing company "Les Gazons de France ", France and by "Golf Saidia Lacs", Saidia, Morocco.

\section{Experimental conditions}

The two tests have been installed at the Experimental Station of the Faculty of Sciences of Oujda, having the following coordinates: an altitude of $661 \mathrm{~m}$, a latitude of $34^{\circ}$ 39 '07' 'North and a longitude of $01^{\circ} 53^{\prime} 01$ 'West (GPS Back Suivre Bushnell). The average monthly rainfall is between $5 \mathrm{~mm}$ and $27 \mathrm{~mm}$ during the spring and between 4 and $16 \mathrm{~mm}$ during the fall. Average monthly temperatures vary between $11^{\circ} \mathrm{C}$ and $35^{\circ} \mathrm{C}$. Maximum values may exceed $40^{\circ} \mathrm{C}$ while absolute minima may drop below $0^{\circ} \mathrm{C}$ (Table 2). Seedling occurred in the spring (April 28) and autumn (October 14) of 2017.

This study compared lawn establishment by six turf grass species seeded in two distinct seasons and widely adopted in the spring (April) and autumn (October) seasons.

\section{Conduction of experiment}

The seedling was carried out in basins with the following dimensions $0.36 \mathrm{~m} \times 0.31 \mathrm{~m} \times 0.24 \mathrm{~m}$ (surface area of 0.11 $\mathrm{m} 2$ ) filled with a substrate composed of $2 / 3$ peat and $1 / 3$ sand.

Seedling doses are those recommended for each species as shown in Table 3 (Bernd et al., 2010). A light watering has been conducted twice day in spring and autumn in order to keep the moist substrate. After emergence, the water applied dose was made according to the city's ETO. During this period, no nutrient inputs were made and no pests were observed except for the appearance of a few weeds that were removed manually without the use of herbicides. Also, mowing was done once for all species except Poa pratensis, which has not been mowed because this species is slow to establish.

Each test is conducted in the field using a Randomized Complete Block Design (RCBD) with three replications.

\section{Parameters measured \\ Coverage rate}

The coverage rate of the turf grass has been controlled two times per week using digital images taken using a digital camera (Canon EOS 550D) in JPEG format (joint photo graphic experts group, .jpg) throughout the trial period from the beginning of the establishment to the end. The digital images were analyzed to determine the percentage of green vegetation cover by quantifying the percentage of the ground surface covered by the plant (Fig 6).

The areas covered by the turf were evaluated using a digital image analysis process comprising: (1) acquisition of digital images. (2) extraction of red, green and blue levels (RGB) of all pixels of images acquired with ImageJ (3) conversion of RGB levels in parameters of Hue, Saturation and Brightness (HSB) (Adobe Systems, 2002), and (4) Creation of an index of color of the turf from the values of HSB, called the index of dark green color (DGCI) (Karcher and Richardson, 2003). ImageJ is a Java software from public domain which has been used in medical imaging, in materials sciences and optical microscopy in the light (Collins, 2007). A plugin in ImageJ was developed using Java to quantify the color parameters of turf images (Oracle Corporation, 2013). This set of plugins quantifies hue angle (on a scale of 0 to $360^{\circ}$ ), the saturation (on a scale of zero to one), and brightness (on a scale of zero to one) (Karcher and Richardson, 2003).

\section{Statistical analysis}

The results were subjected to descriptive statistical analysis and analysis of variance (ANOVA) using the software "SPSS for Windows version 20" and the comparison of means was performed by Tukey's test at the $0.05 \%$ probability threshold.

Table 1. Cool-seasons and warm-seasons species studied.

\begin{tabular}{lll}
\hline Species & Varieties & Region \\
\hline Lolium perenne & ALBOKA & \\
Festuca arundinacea & FIRECRACKER & Temperate \\
Agrostis stolonifera & PENNCROSS & \\
Poa pratensis & PRINCETON & \\
Pennisetum clandestinum & KIKUYO & Tropical \\
Cynodon dactylon & Not determined & \\
\hline
\end{tabular}


Table 2. Climate Data recorded during the year 2017.

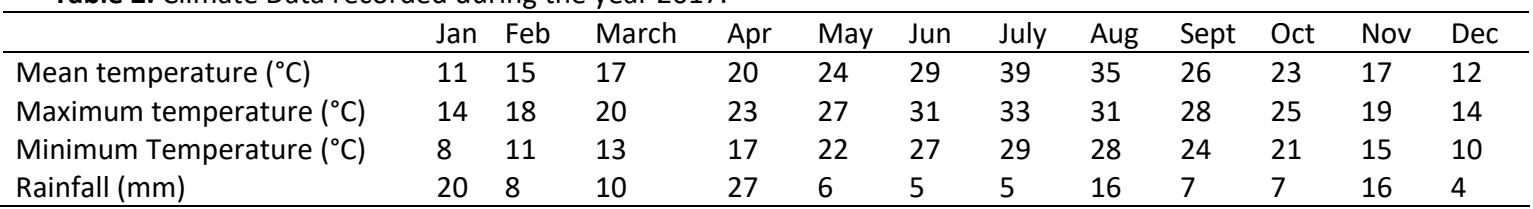

Table 3. Recommended doses for each species.

\begin{tabular}{lll}
\hline Species & Varieties & Recommended Seedling Dose $\left(\mathrm{g} / \mathrm{m}^{2}\right)$ \\
\hline Lolium perenne & ALBOKA & 10 à 20 \\
Festuca arundinacea & FIRECRACKER & 30 à 35 \\
Agrostis stolonifera & PENNCROSS & $05-08$ \\
Poa pratensis & PRINCETON & $10-15$ \\
Pennisetum clandestinum & KIKUYO & $5-15$ \\
Cynodon dactylon & Non déterminée & $10-15$ \\
\hline
\end{tabular}

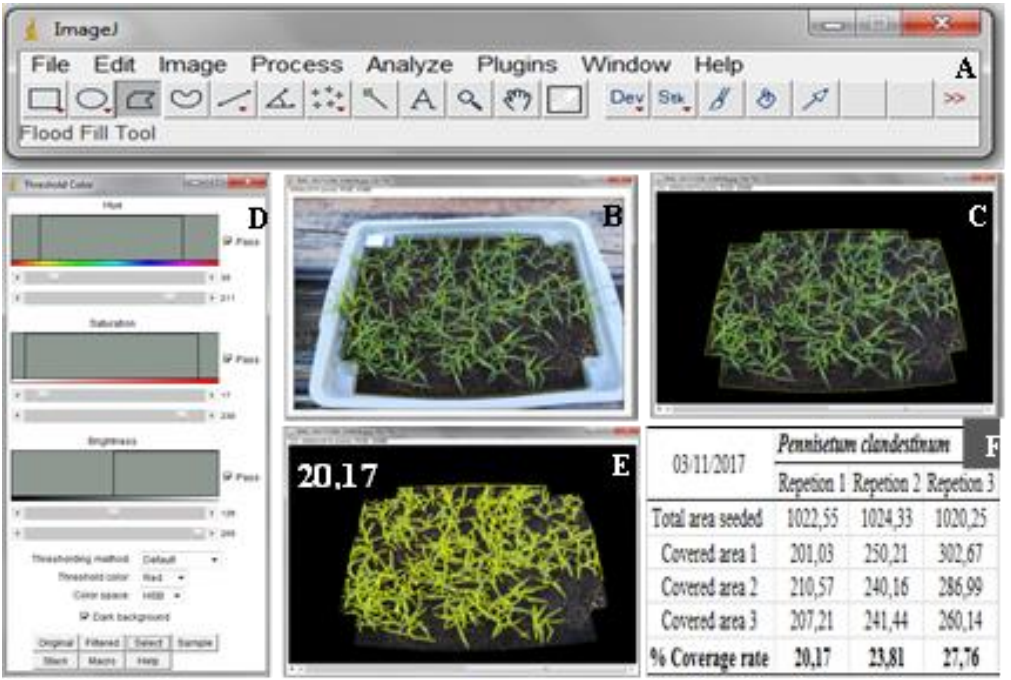

Fig 6. Steps to calculate the coverage rate and Digital Image Analysis process from ImageJ (case of Pennisetum clandestinum) (A) Opening the main ImageJ interface: (B) Input original image in ImageJ, (C) Selecting the covered area with selection tools integrated in the toolbar tools, (D) obtaining the average RGB pixel levels for the image from threshold color (coloring of the turfgrass), (E) coloring in yellow to deduce the covered area, (F) deduction of the coverage rate from the covered area calculated in (E) and it is determined by the following relation: \% Coverage rate $=100 \times$ (total area seeded + covered area $1+$ covered area $2+$ covered area 3$) /(3 \times$ total area seeded)

\section{Conclusion}

The speed of establishment of turf grass is an important criterion the when it comes to choosing the turf grass species. The results obtained under the climatic conditions of the eastern region of Morocco that were recorded during the test period show that the establishment period and the type of turf grass are important criteria for establishing a grassed green space. In fact, it appears that the favourable period for temperate species is autumn, whereas tropical species establish better during spring.

Among the studied species, Lolium perenne and Cynodon dactylon are the fastest to establish followed by the species: Festuca arundinaceae, Pennisetum clandestinum and Agrostis stolonifera. Poa pratensis is the slowest establishing species especially if seeded in spring. Therefore, particular attention must be given to the choice of species to be established while taking into account the climatic conditions of the receiving environment and the type of turf grass (football field or golf course, green space of pleasure, etc.).

\section{Acknowledgments}

we are very grateful to Mr: OTOUYA Said (INRA, Oujda), CHETOUANI Mohammed (LAPIBE, FSO) and Mr Lahcen KHAMOU, (Company *les gazons de France*, France) and RAHMANI Mohammed (PhD, LNOLA, FSO) for their support to this work.

\section{References}

Adobe systems (2002) Adobe Photoshop v. 7.0. Adobe Systems, San Jose CA.

Beard JB (1973) Turfgrass science and culture. PH Englewood Cliffs, New Jersey. 658.

Bernd L, Matteo S, Devesh S (2010) Seed coating and seeding rate effects on turfgrass germination and establishment. HortThecnology. 20 (1): 179-185.

Brock JL, Anderson LB, Lancashire JA (1982) 'Grasslands Roa' tall fescue seedling growth and establishment. New Zeal J Agr Res. 10 (3): 285-289. In: Hare MD (1994) Autumn establishment of three New Zealand cultivars of tall fescue (Festuca arundinacea Schreb.) for seed production. New Zeal J Agr Res. 37(1): 11-17.

Burton GW (1992) Breeding improved turfgrasses. In: Waddington DV, Carrow RN, Shearmann RC (ed) Turfgrass. Crop Sci ASA SA SSSA, Madison. 759. 
Busey P (2003a) Bahiagrass, Paspalum notatum Flugge. In: Casler MD, Duncan RR (ed) Turfgrass biology, genetics and breeding. Wiley, Hoboken. 384.

Christians N (1998) Fundamentals of turfgrass management. Ann Arbor Press Chelsea MI. 312.

Collins TJ (2007) ImageJ for microscopy. Biotechniques. 43:25-30.

Dunn J, Diesberg K (2004) Turf management in the transition zone. Wiley, Hoboken. 288.

Gibeault VA, Leonard M, Cockerham S (1988) Nitrogen fertilization of 'El Toro' zoysiagrass. Calif Turfgrass Cult. 38:4-5.

Guertal EA, Evans DL (2006) Nitrogen rate and mowing height effects on tifeagle bermudagrass establishment. Crop Sci. 46:1772-1778.

Hoffman L, DaCosta M, Ebdon JS, Zhao J (2012) Effects of drought preconditioning on freezing tolerance of perennial ryegrass. Environ Exp Bot. 79:11-20.

Hoffman L, Ebdon JS, Dest WM, DaCosta M (2010) Effects of nitrogen and potassium on wear mechanisms in perennial ryegrass i wear tolerance and recovery. Crop Sci. 50:357-366.

Hoffman L, DaCosta M, Ebdon JS, Watkins E (2010) Physiological changes during cold acclimation of perennial ryegrass accessions differing in freeze tolerance. Crop Sci. 50:1037-1047.

Huff DR (2003) Kentucky bluegrass. In: Casler MD, Duncan RR (ed) Turfgrass biology genetics, and breeding. Wiley, Hoboken. 384.

Hulke B, Watkins E, Wyse D, Ehlke N (2008) Freezing tolerance of selected perennial ryegrass (Lolium perenne L.) accessions and its association with field winter hardiness and turf traits. Euphytica. 163:131-141.

Hull AC Jr (1948) Depth, season, and row spacing for planting grasses on southern idaho range lands. J Amer Sot Agron. 40:960969.

Jiang Y, Huang B (2000) Effects of drought or heat stress alone and in combination on kentucky bluegrass. Crop Sci. 40:1358-1362.

Johnson BJ (1973) Herbicides, sprigging rates, and nitrogen treatments for establishment of Tifway bermudagrass. Agron J. 65:969-972.

Karcher DE, Richardson MD (2003) Quantifying turfgrass color using digital image analysis. Crop Sci. 43:943-951.

Keskin M, Dodd RB, Han YJ, Khalilian (2003) Predicting visual quality ratings of turfgrass research plots using spectral reflectance. Conference ASA Engineers, annual international meeting, At Las Vegas, Nevada, USA, 27-30 July 2003.

Krans JV, Morris K (2007) Determining a profile of protocols and standards used in the visual field assessment of turfgrasses: A survey of national turfgrass evaluation program-sponsored university scientists. Online. Applied Turfgrass Science. doi:10.1094/ATS-2007-1130-01-TT.

Lang R, Rauzi F, Seamands W, Howard G (1975) Guidelines for seeding dryland range, pasture, and disturbed lands. bulltin 621, Wyoming Agriculural experemnt station, university of Wyoming. 11.

Lukina EV, Stone ML, Raun WR (1999) Estimating vegetation coverage in wheat using digital images. J Plant Nutr. 22:341-350.

Mirik M, Michels GJ, Kassmzhanova-Mirik JRS, Elliott NC, Catana V, Jones DB, Bowling R (2006) Using digital image analysis and spectral reflectance data to quantify damage by greenbug (Hemiptera: Aphididae) in winter wheat. Comput Electron Agric. 51:86-98.

Morris KN, (2002) A guide to NTEP turfgrass rating. A publication of the national turfgrass evaluation program. Beltsville, MD NTEP. 11:30-39.

Munshaw GC, Williams DW (2002) Enhancing stolon production of seeded bermudagrass. Golf Course Management. 70(2):53-56.

Munshaw GC, Williams DW, Powell Jr AJ, Dougherty CT (1998) Growth and development of seeded versus vegetative bermudagrass varieties. In: annual meetings abstracts. ASA CSSA and SSSA, Wisconsin, Madison, 136.

Oracle Corporation (2013) Java platform. Enterprise (ed) 7 Oracle Corp, Redwood shores, CA.
Patton AJ, Hardebeck GA, Williams DW, Reicher ZJ (2004) Establisment of bermudagrass and zoysiagrass by seed. Crop Sci. 44:2160-2167.

Perez A, Harwood J, Johnson D, Somwani A, Zepp G (1995) Turfgrass sod: An economic assessment of the feasibility of providing multiple-peril crop insurance. Report prepared by the economic research service, United States department of agriculture for the federal crop insurance corporation. Available at: http://www. Rma.Usda. gov / pilots / feasible / PDF / turfsod. Pdf.

Portz HL, Murray JJ, Yeam DY (1981) Zoysiagrass (Zoysia japonica Steud.) establishment by seed. Int Turfgrass Soc Res J. 4:113-122.

Purcell LC (2000) Soybean canopy coverage and light interception measurement using digital imagery. Crop Sci. 40:834-837.

Reicher ZJ, Throssell CS, Weisenberger DV (2000) Date of seeding affects establishment of cool-season turfgrasses. HortScience 35:1166-1169.

Richardson MD, Karcher DE, Berger P, Boyd JW (2004) Utilizing improved seeded bermudagrass on transition-zone sports fields. Acta Hort. 661:369-374.

Richardson MD, Karcher DE, Hignight K, Rush DE (2008) Drought tolerance and rooting capacity of kentucky bluegrass cultivars. Crop Sci. 48:2429-2436.

Richardson MD, Karcher DE, Purcell LC (2001) Quantifying turfgrass cover using digital image analysis. Crop Sci. 41:1884-1888.

Ries RE, Hofmann L (1996) Perennial grass establishment in relationship to seeding dates in the Northern Great Plains. J Range Manag. 49(6): 504-508.

Roche MB, Loch DS (2005) Morphological and developemental comparison of seven greens quality hybrid bermudagrass [Cynodon dactylon (L.) Pers. x C. transvaalensis Burtt-Davy] cultivars. Int Turfgrass Soc Res J. 10:627-634.

Rodriguez IR, Miller GL, McCarty LB (2000) Sprigged bermudagrass needs ample phosphorus at growin. Golf Course Management. 68(6):59-62.

Ruemmele BA, Engelke MC, Morton SJ, White RH (1993) Evaluating methods of establishment for warm-season turfgrasses. Int Turfgrass Soc Res J. 7:910-916.

Schiavon M, Leinauer B, Serena M, Sallenave R, Maier B (2012) Bermudagrass and seashore paspalum establishment from seed using differing irrigation methods and water qualities. Agron J. 104:706-714.

Shaver BR, Richardson MD, McCalla JH, Karcher DE, Berger PJ (2006) Dormant seeding bermudagrass cultivars in a transition-zone environment. Crop Sci. 46:1787-1792.

Smiley RW, Dernoeden PH, Clarke BB (1992) Compendium of turfgrass diseases. 2nd edn. APS, Saint Paul, Minnes ota, ÉtatsUnis. 98.

Stier JC (2000) Lawn establishment and renovation. Extention bulletin A3434, University Wisconsin. Madison, 2000.

Stier JC, Koeritz EJ, Garrison M (2008) Timing the establishment of kentucky bluegrass: perennial ryegrass mixtures for football fields. HortScience 43(1):240-244.

Trenholm LE, Carrow RN, Duncan RR (1999) Relationship of multispectral radiometry data to qualitative data in turfgrass research. Crop Sci. 39:763-769

Trenholm LE, Dudeck AE, Sartain JB, Cisar JL (1997) Cynodon responses to nitrogen potassium, and day-length during vegetative establishment. Int Turfgrass Soc Res J. 8:541-552.

Ward CY, McWhirter EL, Thompson Jr WR, (1974) Evaluation of coolseason turf species and planting techniques for overseeding bermudagrass golf greens. In: Roberts EC (ed) Proceedings of the second international turfgrass research. Conference, Blacksburg, Virginia, ASA, Madison, Wisconsin, June 1973.

Watschke TL, Schmidt RE (1992) Ecological aspects of turf communities mowing. In: Waddington DV, Carrow RN, Shearmann RC, (ed) Turfgrass Agronomy monograph 32, ASA, CSSA and SSSA, Madison, Wisconsin. 149-151.

Watson JR (1989) The USGA research committee activities with particular reference to the utilization, problems and perspective of zoysiagrass in the USA. In: Takatoh $\mathrm{H}$, (ed), Proceeding of 6 th conference Int Turfgrass Soc Res, 31 July-5 Aug, 1989. 